Review Article

\title{
The use of antimicrobial-impregnated fabrics in health services: an integrative review*
}

\author{
Guilherme Schneider ${ }^{1,2}$ \\ (D) https://orcid.org/0000-0002-4244-6217 \\ Felipe Lazarini Bim ${ }^{1,2}$ \\ (D) https://orcid.org/0000-0003-4190-536X \\ Álvaro Francisco Lopes de Sousa ${ }^{13,4}$ \\ (D) https://orcid.org/0000-0003-2710-2122 \\ Evandro Watanabe ${ }^{5}$ \\ (1D) https://orcid.org/0000-0001-5674-2589 \\ Denise de Andrade ${ }^{1,4}$ \\ (D) https://orcid.org/0000-0002-3336-2695 \\ Inês Fronteira ${ }^{3}$ \\ (iD) https://orcid.org/0000-0003-1406-4585
}

Objective: to analyze evidence concerning the feasibility of antimicrobial-impregnated fabrics in preventing and controlling microbial transmission in health services. Method: an integrative review using the following databases: MEDLINE (via PubMed), Web of Science, Cumulative Index to Nursing and Allied Health Literature (CINAHL), Scopus, and Latin American and Caribbean Health Sciences Literature (LILACS), regardless of language and date of publication. Seven studies were included in the analysis to verify the types of fabrics and substances used to impregnate the fabrics, applicability in health services, and decrease in microbial load. Results: silver nanoparticles and copper oxide are the main antimicrobial substances used to impregnate the fabrics. The patients' use of these fabrics, such as in bed and bath linens and clothing, was more effective in reducing antimicrobial load than in health workers' uniforms. Conclusion: the use of these antimicrobial-impregnated textiles, especially by patients, is a viable alternative to prevent and control microbial transmission in health services. Implementing these fabrics in health workers' uniforms requires further studies, however, to verify its effectiveness in decreasing microbial load in clinical practice.

Descriptors: Containment of Biohazards; Infection Control; Health Services; Protective Clothing; Textiles; Anti-Infective Agents.

\section{How to cite this article}

Schneider G, Bim FL, Sousa AFL, Watanabe E, Andrade D, Fronteira I. The use of antimicrobial-impregnated fabrics in health services: an integrative review. Rev. Latino-Am. Enfermagem. 2021;29:e3416. [Access Available in: DOI: http://dx.doi.org/10.1590/1518-8345.4668.3416. 


\section{Introduction}

Healthcare-Associated Infections (HAIs) account for increased morbidity and mortality, lengthier hospitalizations, increased healthcare costs, and favor the selection and dissemination of multi-drug resistant microorganisms ${ }^{(1)}$. In this sense, it is essential to pay attention to the various fabrics used in healthcare settings, considering that both fabrics worn by workers, such as in coats and uniforms, and those used by patients like in bed and bath linens and gowns play an essential role in microbial contamination and transmission(2).

Coats are widely worn at all healthcare levels as a barrier to protect workers against exposure to body fluids and infectious agents; their protective role against microbial contamination is often overestimated though ${ }^{(3-4)}$. Hence, attention should be paid to the possibility of coats and clothing being contaminated, especially when hand hygiene is neglected, considering that hand hygiene is vital to break the chain of microbial transmission(5-6).

Another aspect to be considered refers to how frequently coats are washed. Results reported by a systematic review show that from $5 \%$ to $65 \%$ of the health workers wash their coats only once every two weeks. This situation is even more critical among health care students, who report washing coats every three weeks and a half(7). This fact is of concern because the low frequency at which coats are sanitized may promote microbial proliferation and transmission. Thus, unwashed coats worn in health services are more likely to take part in the chain of infection.

In addition to coats, the fabrics used by patients in health services represent an important threat as a source of microbial cross-contamination and transmission ${ }^{(2)}$. This motivates industries to invest in technology to implement alternative resources and options with antimicrobial properties $^{(8-9)}$

Fabrics with enhanced functionality are currently available for a wide range of applications. They are of great interest in the healthcare field due to their ability to prevent or inhibit the growth of microorganisms, inhibit the formation of biofilms, or impede microbial propagation, thus removing sources of infection(10-11). Note, however, that there is a gap between scientific knowledge concerning the use of these different fabrics in healthcare services, their potential or ineffectiveness to decrease microbial contamination, and their association with potential applicability.

The development of Personal Protective Equipment (PPEs) with enhanced features, such as coats impregnated with antimicrobials to be worn by health workers, as well as the use of fabrics with these properties by hospitalized patients, can become an alternative to mitigate the current pandemic caused by the Coronavirus Disease 2019 (COVID-19). The cause of this respiratory infection is the etiological agent Coronavirus 2 Severe Acute Respiratory Syndrome Coronavirus 2 (SARS-CoV-2), which, up to August $2^{\text {nd }}, 2020$, had led to 680,894 deaths $^{(12)}$. This virus can spread through respiratory droplets ${ }^{(13)}$ that contaminate surfaces, including fabrics.

The viability of the SARS-CoV-2 varies according to the characteristics of surfaces, while viral loads are undetectable on the second day of contact with textile surfaces $^{(14)}$. Therefore, patients' gowns and health workers' uniforms are vehicles that transmit SARS-CoV-2(15), even if for a relatively short period.

The United States of America, the current epicenter of the COVID-19 pandemic, has recorded 120,467 cases of infection among health workers $^{(16)}$, despite recommendations to expand diagnostic tests(17). Even though we cannot assume the real factors leading to these epidemiological data, the use of textiles impregnated with antimicrobial substances in healthcare services can turn SARS-CoV-2 ineffective, and consequently, promote the biological protection necessary for workers and patients.

Given the previous discussion, this study's objective was to analyze evidence concerning the viability of fabrics impregnated with antimicrobial substances in preventing and controlling microbial transmission in health services.

\section{Method}

This is an integrative review, characterized by the ability to group and synthesize relevant scientific evidence regarding a specific topic or guiding question, contributing to understanding knowledge deeper and better by providing a portray of the literature at a given time ${ }^{(18)}$.

This study was conducted in five stages, namely: the establishment of a clear and objective question based on the identification of a problem; search for primary scientific studies; assessment of studies according to previously established inclusion and exclusion criteria; critical analysis; characterization of the studies selected to compose the review; and presentation ${ }^{(18)}$.

The study question was established using the $\mathrm{PICo}^{(19)}$ strategy:

- Problem $(P)=$ Microbial load;

- Intervention (I) = Fabrics impregnated with antimicrobial substances;

- Context $(\mathrm{Co})=$ Health care services

Hence, the following question was established: "Is the use of fabrics impregnated with antimicrobial substances in health services a viable alternative to decrease microbial load?" 
The search in the scientific literature was conducted in April 2020 in the following databases: MEDLINE via the PubMed portal of the US National Library of Medicine, Web of Science (WoS), Cumulative Index to Nursing and Allied Health Literature (CINAHL), Scopus, and Latin American and Caribbean Health Sciences (LILACS) via Virtual Health Library (VHL) portal.

The following combination of keywords was used based on the terms adopted in the PICo strategy; (roupa* OR têxt*) AND impregna* AND antimicrob* (Portuguese) and (cloth* OR textil*) AND impregna* AND antimicrobial* (English), respecting the databases' specificities. No filters were used to restrict study designs, timeframe, or language, to expand the bibliographic search.

The search in the different scientific databases resulted in 285 studies (MEDLINE $=49$, Web of Science $=90$, CINAHL=14, Scopus=131, LILACS=1), which were manually selected and exported using Microsoft Excel ${ }^{\circledR}$ version 2016.

Inclusion and exclusion criteria were also based on the PICo strategy. Thus, the following inclusion criteria were used: studies with an intervention or in vitro design addressing fabrics impregnated with antimicrobial substances designated to be used in health services, assessing microbial load and/or HAIs rates, published up to 2020, written in any language, with full texts available online. Exclusion criteria were: literature reviews, editorials, expert opinions, experience reports, letters, and papers that did not fit the scope of this review.

Therefore, two researchers with expertise in the field selected the studies to compose this review's final sample. The studies were assessed in two stages: assessment of titles and abstracts and assessment of the full texts. Each researcher independently conducted both stages. After the researchers finished the assessments, they met to discuss and reach a consensus regarding the inclusion and exclusion criteria used to select the studies. A third researcher would mediate potential disagreements, but this was not necessary.

In total, 120 duplicated studies were excluded, and the titles and abstracts of 165 studies were analyzed, regardless of language or date of publication, to verify whether they answered the guiding question. In this stage, the sample was reduced to 76 studies. Another 69 studies were excluded after the full texts were read either because they did not address health services; that is, fabrics impregnated with antimicrobial substances were not used by patients or health workers, or the authors did not specify whether the enhanced fabrics were designated to health services. Hence, the final sample included seven studies.

To avoid methodological biases, two researchers analyzed and characterized the selected studies. Hence, the studies were carefully read, and data considered relevant to answer the guiding question were extracted. A form was specifically developed to guide this process and addressed: identification (reference), method, types of impregnated fabrics, types of substances used, specific applicability/use of the fabrics in health services, main results, limitations, and quality of evidence.

The quality of evidence reported by the studies included in this review was classified into high, moderate, low, or very low, according to the Grading of Recommendations Assessment, Development and Evaluation (GRADE) ${ }^{(20)}$.

\section{Results}

The search in the scientific literature for conclusive answers to the question regarding the feasibility of using fabrics impregnated with antimicrobial substances in health care services resulted in seven studies, presented in Figure 1.

All the studies included in this integrative review were written in English and published between 2010 and 2017. Most studies, approximately $86 \%$, were identified in PubMed - MEDLINE. The information extracted from these original studies concerned the methods used, types of fabrics, antimicrobial substances used to impregnate the textiles, and applicability in the health services. The main results are presented in Figure 2 .

In general, the studies' objectives were to compare levels of microbial contamination and/or incidence of HAIs between regular fabrics and antimicrobialimpregnated fabrics through laboratory analyses or in the real context of health care services. Of the seven studies selected for analysis, five are intervention studies, and two are in vitro studies. The fabrics used were cotton and polyester. The main substances with antimicrobial properties used to impregnate the fabrics were: copper oxide and silver nanoparticles. The fabrics were used for bed and bath linens, patients' clothing, and health workers' uniforms. The use of these textiles among patients as bed and bath linens and clothing was more efficient than as health workers' uniforms to decrease the microbial load. 


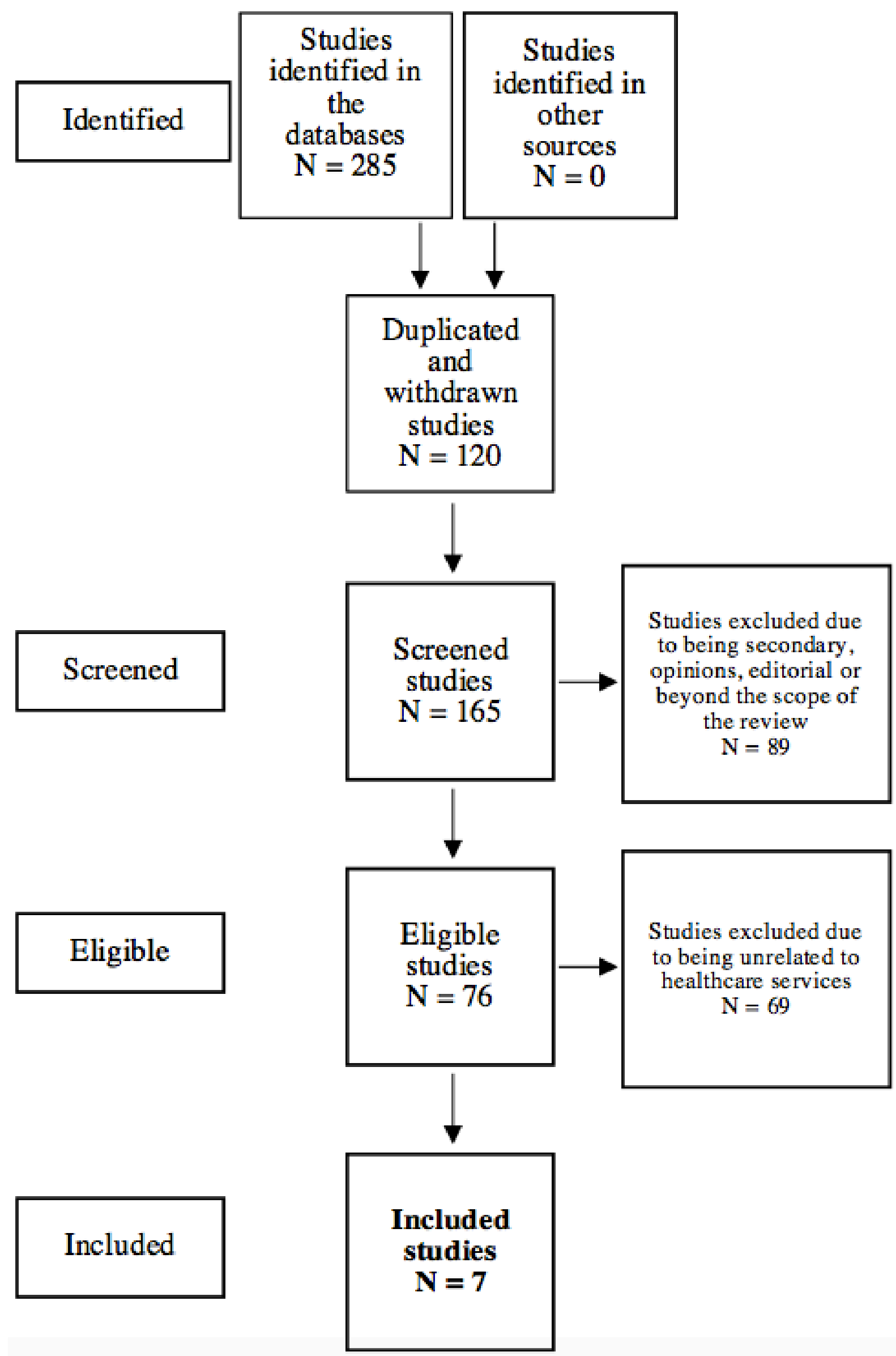

Figure 1 - Studies selection flowchart, adapted from the Preferred Reporting Items for Systematic Review and MetaAnalyses (PRISMA), regarding the use of fabrics impregnated with antimicrobial substances in health care services 


\begin{tabular}{|c|c|c|c|c|c|c|}
\hline Code & $\begin{array}{l}\text { Identification } \\
\text { (reference) }\end{array}$ & Method & $\begin{array}{c}\text { Textile, } \\
\text { substance and } \\
\text { applicability }\end{array}$ & Main results & Limitations & $\begin{array}{l}\text { Quality of } \\
\text { evidence }\end{array}$ \\
\hline A1 & $\begin{array}{l}\text { Marcus, et al. } \\
(2017)^{(21)}\end{array}$ & $\begin{array}{l}\text { Seven-month crossover, double- } \\
\text { blind, controlled intervention (two } \\
\text { three-month periods separated } \\
\text { by one month for washout period) } \\
\text { with chronic patients dependent on } \\
\text { mechanical ventilation hospitalized } \\
\text { in two wards of a long-stay care } \\
\text { hospital. In the } 1^{\text {st }} \text { period, one } \\
\text { ward received the copper oxide- } \\
\text { impregnated fabrics while the } \\
\text { other ward received the control } \\
\text { fabrics. In the } 2^{\text {nd }} \text { period, the ward } \\
\text { that first received the impregnated } \\
\text { fabrics received the control fabrics } \\
\text { and vice-versa. The results } \\
\text { were analyzed by comparing the } \\
\text { periods, fever days, the beginning } \\
\text { of the antibiotics treatment, and } \\
\text { daily dose. }\end{array}$ & $\begin{array}{l}\text { - Polyester. } \\
\text { - Copper oxide } \\
\text { at } 1 \% \text {. } \\
\text { - Textile used by } \\
\text { patients: towels } \\
\text { and clothing. }\end{array}$ & $\begin{array}{l}\text { The study shows that } \\
\text { the use of copper oxide- } \\
\text { impregnated textiles used } \\
\text { in long-stay hospitals } \\
\text { decreased HAl }\left.\right|^{s^{*}} \text { indicators } \\
\text { (by } 55.5 \% \text { on days the } \\
\text { patients had a fever, } 29.3 \% \\
\text { at the beginning of the } \\
\text { antibiotics treatment, } 23 \% \\
\text { on days of treatment, and } \\
27.5 \% \text { on daily dose) when } \\
\text { compared to the period when } \\
\text { control fabrics were used. }\end{array}$ & $\begin{array}{l}\text { - Study } \\
\text { conducted in } \\
\text { only two wards } \\
\text { of a single } \\
\text { facility; } \\
\text { - It was not } \\
\text { possible to } \\
\text { determine the } \\
\text { effect of the } \\
\text { intervention on } \\
\text { specific HAls }{ }^{*} \text {. }\end{array}$ & Moderate. \\
\hline A2 & $\begin{array}{l}\text { Irfan, et al. } \\
(2017)^{(22)}\end{array}$ & $\begin{array}{l}\text { In vitro controlled study, in which } \\
\text { a coating, composed of silver } \\
\text { nanoparticles embedded in a } \\
\text { silica matrix, was deposited by } \\
\text { radiofrequency co-sputtering } \\
\text { on cotton-fabric designated for } \\
\text { surgical gowns. The antimicrobial } \\
\text { properties of the samples of } \\
\text { coated fabrics and control fabrics } \\
\text { (uncoated) were assessed using } \\
\text { the inhibition halo test against } \\
\text { gram-positive (Staphylococcus } \\
\text { aureus) and gram-negative } \\
\text { (Escherichia coli) bacteria and } \\
\text { against yeast (Candida albicans). } \\
\text { Additionally, the treated fabric } \\
\text { was characterized in terms of its } \\
\text { physical properties and functional } \\
\text { performance. }\end{array}$ & $\begin{array}{l}\text { - Cotton. } \\
\text { - Silver } \\
\text { nanoparticles } \\
\text { embedded in } \\
\text { silica matrix. } \\
\text { - Surgical scrubs. }\end{array}$ & $\begin{array}{l}\text { The treated fabric presented } \\
\text { antimicrobial activity } \\
\text { against the microorganisms } \\
\text { analyzed. The treated } \\
\text { fabrics samples displayed } \\
\text { an inhibition halo of } 2 \text { to } 3 \\
\text { mm against Staphylococcus } \\
\text { aureus and } 1 \text { to } 2 \text { mm } \\
\text { against Candida albicans. } \\
\text { On the other hand, the } \\
\text { growth of Escherichia coli } \\
\text { was not completed inhibited } \\
\text { with the technique used. } \\
\text { Moreover, the control fabrics } \\
\text { presented no antimicrobial } \\
\text { activities against the strains } \\
\text { analyzed, with microbial } \\
\text { growth on the samples' } \\
\text { surface. }\end{array}$ & $\begin{array}{l}\text { - The tests were } \\
\text { performed with } \\
\text { only two species } \\
\text { of bacteria and } \\
\text { one fungus; } \\
\text { - No in vivo tests } \\
\text { were performed, } \\
\text { despite } \\
\text { the toxicity } \\
\text { assessment. }\end{array}$ & Very low \\
\hline A3 & $\begin{array}{l}\text { Anderson, et } \\
\text { al. }(2017)^{(23)}\end{array}$ & $\begin{array}{l}\text { Controlled, crossover, randomized, } \\
\text { blinded intervention conducted } \\
\text { with the nurses of two ICUs }{ }^{\dagger} \text { at a } \\
\text { tertiary hospital. The participants } \\
\text { received three different surgical } \\
\text { scrubs: standard cotton- } \\
\text { polyester (control) scrubs, scrubs } \\
\text { impregnated with a silver-alloy, } \\
\text { or scrubs impregnated with } \\
\text { organosilane-based quaternary } \\
\text { ammonium and a hydrophobic } \\
\text { fluorinated acrylate copolymer } \\
\text { emulsion. Each nurse wore } \\
\text { surgical scrubs during } 12 \text {-hour } \\
\text { consecutive shifts so that all the } \\
\text { nurses participated in the control } \\
\text { group and the two interventions. } \\
\text { The scrubs' microbial load was } \\
\text { determined before and after each } \\
\text { work shift. }\end{array}$ & $\begin{array}{l}\text { - Cotton and } \\
\text { polyester. } \\
\text { - Intervention 1: } \\
\text { silver alloy. } \\
\text { - Intervention 2: } \\
\text { organosilane- } \\
\text { based quaternary } \\
\text { ammonium and } \\
\text { a hydrophobic } \\
\text { fluorinated } \\
\text { acrylate } \\
\text { copolymer } \\
\text { emulsion } \\
\text { - Surgical scrubs. }\end{array}$ & $\begin{array}{l}\text { The surgical scrubs } \\
\text { impregnated with } \\
\text { antimicrobials were not } \\
\text { effective in decreasing } \\
\text { the nurses' microbial } \\
\text { contamination compared to } \\
\text { standard surgical scrubs, } \\
\text { during 12-hour shifts in } \\
\text { ICUs'. }\end{array}$ & $\begin{array}{l}\text { - Study } \\
\text { conducted in } \\
\text { only two ICUs }{ }^{\dagger} \text { of } \\
\text { a single facility; } \\
\text { - The culture of } \\
\text { microorganisms } \\
\text { was obtained } \\
\text { from random } \\
\text { spots of the } \\
\text { surgical scrubs, } \\
\text { which may have } \\
\text { failed to show } \\
\text { the real extent of } \\
\text { colonization. }\end{array}$ & Moderate. \\
\hline A4 & $\begin{array}{l}\text { Gerba, et al. } \\
(2016)^{(24)}\end{array}$ & $\begin{array}{l}\text { Controlled in vitro study comparing } \\
\text { antimicrobial activity in cotton } \\
\text { fabrics impregnated with silver } \\
\text { and untreated cotton fabrics } \\
\text { (control) } 2,4 \text {, and } 24 \text { hours after } \\
\text { the fabrics had been exposed to } \\
\text { the following microorganisms: } \\
\text { Escherichia coli, Salmonella } \\
\text { choleraesuis, vancomycin- } \\
\text { resistant Enterococcus faecium, } \\
\text { carbapenem-resistant Klebsiella } \\
\text { pneumoniae, methicillin-resistant } \\
\text { Staphylococcus aureus, } \\
\text { Clostridium difficile spores, } \\
\text { Propionibacterium acnes, } \\
\text { Trichophyton mentagrophytes, } \\
\text { MS2 coliphage, murine norovirus. }\end{array}$ & $\begin{array}{l}\text { - Cotton. } \\
\text { - Silver. } \\
\text { - Uniforms worn } \\
\text { by health workers } \\
\text { and fabrics used } \\
\text { by patients: } \\
\text { sheets and } \\
\text { pillowcases. }\end{array}$ & $\begin{array}{l}\text { The silver-impregnated fabric } \\
\text { presented antimicrobial } \\
\text { efficacy against all the } \\
\text { microorganisms analyzed. } \\
\text { Clostridium difficile spores } \\
\text { were the most resistant; } \\
\text { a decrease of } 90 \% \text { was } \\
\text { verified after } 96 \text { hours } \\
\text { though. The conclusion is } \\
\text { that fabrics impregnated } \\
\text { with antimicrobial agents } \\
\text { can work as a barrier to } \\
\text { control the transmission of } \\
\text { microorganisms within health } \\
\text { services. }\end{array}$ & $\begin{array}{l}\text { - No in vivo tests } \\
\text { were performed; } \\
\text { - No toxicity } \\
\text { assessment was } \\
\text { reported. }\end{array}$ & Very low \\
\hline
\end{tabular}


(Figure 2 continuation...)

\begin{tabular}{|c|c|c|c|c|c|c|}
\hline Code & $\begin{array}{c}\text { Identification } \\
\text { (reference) }\end{array}$ & Method & $\begin{array}{c}\text { Textile, } \\
\text { substance and } \\
\text { applicability }\end{array}$ & Main results & Limitations & $\begin{array}{l}\text { Quality of } \\
\text { evidence }\end{array}$ \\
\hline A5 & $\begin{array}{l}\text { Sifri, Burke, } \\
\text { Enfield (2016) } \\
(25)\end{array}$ & $\begin{array}{l}\text { Controlled, quasi-experimental } \\
\text { intervention study, conducted } \\
\text { during the replacement of an old } \\
\text { clinical wing by a new one in an } \\
\text { acute care hospital. The study } \\
\text { lasted } 25.5 \text { months, divided into } \\
\text { baseline (before the old wing } \\
\text { was replaced with a duration } \\
\text { of } 12 \text { months) and assessment } \\
\text { (after the old wing was replaced } \\
\text { with a duration of } 10 \text { months). } \\
\text { There was an interval between } \\
\text { the two periods to implement the } \\
\text { surfaces and fabrics impregnated } \\
\text { with copper oxide in the new } \\
\text { hospital wing wards. During the } \\
\text { assessment period, the patients } \\
\text { hospitalized in an unmodified } \\
\text { hospital wing and the new } \\
\text { hospital wing were assessed. The } \\
\text { incidence of HAls* was compared } \\
\text { between both periods. }\end{array}$ & $\begin{array}{l}\text { - The type of } \\
\text { textile used is not } \\
\text { described. } \\
\text { - Copper oxide. } \\
\text { - Textiles used by } \\
\text { patients: sheets, } \\
\text { pillowcases, } \\
\text { covers, towels, } \\
\text { cloths, and } \\
\text { clothing. }\end{array}$ & $\begin{array}{l}\text { Compared to the baseline, } \\
\text { the incidence of HAls } \\
\text { caused by multi-drug } \\
\text { resistant organisms } \\
\text { or Clostridium difficile } \\
\text { decreased by } 78 \% \text { in the } \\
\text { new hospital wing. The } \\
\text { unmodified hospital wing } \\
\text { showed no changes in the } \\
\text { rate of HAls* in comparison } \\
\text { to baseline. The conclusion } \\
\text { is that surfaces and fabrics } \\
\text { impregnated with copper } \\
\text { oxide can be useful to } \\
\text { prevent HAls* in hospital } \\
\text { settings. }\end{array}$ & $\begin{array}{l}\text { - Study } \\
\text { conducted in a } \\
\text { single facility; } \\
\text { - The patients } \\
\text { were not blinded } \\
\text { or randomized; } \\
\text { - Surveillance } \\
\text { of HAls* was } \\
\text { retrospective; } \\
\text { - Not possible } \\
\text { to determine } \\
\text { the relative } \\
\text { contribution of } \\
\text { the impregnated } \\
\text { textiles and } \\
\text { surfaces in } \\
\text { reducing HAls*. }\end{array}$ & Moderate \\
\hline A6 & $\begin{array}{l}\text { Lazary, et al. } \\
(2014)^{(26)}\end{array}$ & $\begin{array}{l}\text { Intervention study conducted } \\
\text { during six-month parallel } \\
\text { periods in a brain injury ward } \\
\text { in which inpatients present a } \\
\text { low level of consciousness and } \\
\text { total dependency. Standard } \\
\text { fabrics are assessed in period } \\
\text { A while, during period B, all the } \\
\text { fabrics were replaced by copper } \\
\text { oxide-impregnated fabrics. The } \\
\text { incidence of infection rate was } \\
\text { compared between periods A and } \\
\text { B, considering fever days and } \\
\text { antibiotic treatment. Microbiological } \\
\text { collection and analysis were } \\
\text { performed in the spots in which the } \\
\text { sheets come in contact with the } \\
\text { patients' backs, after six to seven } \\
\text { hours of use. }\end{array}$ & $\begin{array}{l}\text { - Polyester. } \\
\text { - Copper oxide. } \\
\text { - Textiles used by } \\
\text { patients: sheets, } \\
\text { pillowcases, } \\
\text { covers, towels, } \\
\text { and clothing. }\end{array}$ & $\begin{array}{l}\text { The use of copper oxide- } \\
\text { impregnated textiles } \\
\text { decreased the rate of } \\
\text { incidence of HAls by } 24 \% \text {, } \\
\text { on fever days by } 47 \% \text {, } \\
\text { and antibiotic treatment } \\
\text { days by } 32.8 \% \text {, compared } \\
\text { to standard fabrics used } \\
\text { in a long-stay ward. The } \\
\text { microbiological analysis } \\
\text { showed a lower bacterial } \\
\text { load in the copper oxide } \\
\text { impregnated-textiles } \\
\text { compared to untreated } \\
\text { textiles. }\end{array}$ & $\begin{array}{l}\text { - Study } \\
\text { conducted in } \\
\text { only one ward of } \\
\text { a single facility; } \\
\text { - There was no } \\
\text { control group. }\end{array}$ & Low \\
\hline A7 & $\begin{array}{l}\text { Groß, et al. } \\
(2010)^{(27)}\end{array}$ & $\begin{array}{l}\text { Intervention study conducted } \\
\text { with an ambulance staff for } \\
\text { four weeks. During the } 1^{\text {st }} \text { and } \\
3^{\text {rd }} \text { weeks, employees wore } \\
\text { conventional uniforms, and in } \\
\text { the } 2^{\text {nd }} \text { and } 4^{\text {th }} \text { weeks, they wore } \\
\text { silver impregnated-uniforms. The } \\
\text { uniforms were washed before the } \\
\text { beginning of each assessment } \\
\text { week. Samples of jackets and } \\
\text { pants were collected before the } \\
\text { first shifts and on the } 3^{\text {rd }} \text { and } 7^{\text {th }} \\
\text { days after the uniforms were } \\
\text { removed, to assess the bacterial } \\
\text { load. }\end{array}$ & $\begin{array}{l}\text { - The textile } \\
\text { used was not } \\
\text { described. } \\
\text { - Silver. } \\
\text { - Uniforms worn } \\
\text { by emergency } \\
\text { care workers: } \\
\text { jacket and pants }\end{array}$ & $\begin{array}{l}\text { The bacterial load verified } \\
\text { in the silver-impregnated } \\
\text { jackets was } 3.8 \text { and } 2.3 \\
\text { times higher on the } 3^{\text {rd }} \\
\text { and } 7^{\text {th }} \text { days, respectively, } \\
\text { compared to the regular } \\
\text { jackets. Additionally, the } \\
\text { bacterial load found in the } \\
\text { silver impregnated-pants } \\
\text { almost doubled on the } 3^{\text {rd }} \\
\text { days, though it was lower } \\
\text { on the } 7^{\text {th }} \text { days, compared } \\
\text { to the regular pants. That } \\
\text { is, the silver-impregnated } \\
\text { uniforms did not decrease } \\
\text { the bacterial load. }\end{array}$ & $\begin{array}{l}\text { - Pilot study; } \\
\text { - Small sample } \\
\text { size; } \\
\text { - No control } \\
\text { group. }\end{array}$ & Low \\
\hline
\end{tabular}

${ }^{*}$ HAIs = Health-Associated Infections; ${ }^{+}$ICUs = Intensive Care Units

Figure 2 - Characterization of the studies included in the integrative review according to the method, type of textile, and antimicrobial substance used to impregnate the fabrics, applicability in health services, and main results

\section{Discussion}

The use of fabrics impregnated with antimicrobial substances is reported in the scientific literature, decreasing the microbial load in in vitro and intervention studies, specifically when these fabrics are used in the clothing of patients and bed and bath lines of health services. Thus, textiles impregnated with antimicrobial agents may be a viable barrier to control microbial transmission, especially in times of outbreaks.

Three of the studies selected ( $11, A 5$, and A6) report that copper oxide-impregnated fabrics, mainly bed linens and clothing worn by patients, are efficient in decreasing the microbial load, contributing to a decreased occurrence of HAIs ${ }^{(21,25-26)}$. The potential mechanisms of the copper oxide's antimicrobial activity include oxidative 
stress, mainly induced by the formation of peroxides, which destroys microbial structure and DNA, and the nanoparticles' release of metal ions, which adhere to, damage, and waterproof the microorganism membrane, leading to cell death(28).

Due to the various factors intrinsic to the chain of infection transmission, we highlight the mistaken interpretation of the results of the studies ( $1, A 5, A 6)$ reporting that the intervention with fabrics impregnated with antimicrobial agents, especially copper oxide, was responsible for decreased HAIs ${ }^{(21,25-26)}$, with potential to influence changes in clinical practice. This type of intervention may be responsible for decreasing microbial contamination; however, one cannot affirm that it was responsible for decreasing HAIs, considering that there are other variables directly or indirectly linked to the development of infections ${ }^{(29-30)}$.

Silver nanoparticles, in turn, are widely used in the manufacturing of textiles with antimicrobial properties. According to the results reported by one in vitro study using different bacterial strains, the silver nanoparticles' antimicrobial action occurs through oxidative stress, which causes damage to the microorganism DNA ${ }^{(31)}$.

Among the studies included in this integrative review, four (A2, A3, A4, A7) addressed the impregnation of textiles with silver nanoparticles ${ }^{(22-24,27)}$ while the efficacy of the antimicrobial agents ${ }^{(22,24)}$ was only reported in the two in vitro analyses (A2, A4). The two remaining studies $(A 3, A 7)$, in which silver-impregnated textiles were used in the uniforms of health workers during care delivery, report no differences regarding decreased microbial contamination in comparison to conventional fabrics(23,27). Note, however, that the sample size of one of these studies (A7) was small and may not be representative for final analysis(27). Therefore, only one study (A3) reported the antimicrobial ineffectiveness of textiles impregnated with silver nanoparticles used in health services ${ }^{(23)}$, suggesting the need for further studies to support conclusions.

The contextualization of these findings to the context of the COVID-19 pandemic needs to consider that the transmission of the SARS-CoV-2 mainly occurs via direct contact (between contaminated hands and mucosa) and via droplets released by contaminated individuals when speaking, coughing, or sneezing(13). Droplets, and also aerosols ${ }^{(32-33)}$, can contaminate surfaces and fomites so that the clothing of health workers is an essential tool to promote biosafety and the quality of health care delivery(34-35).

Nonetheless, the risk of contamination and infection is enhanced when inappropriately dressing and removing the PPE. This is of concern, considering that a study verified, through a clinical simulation of COVID-19-related cases, mistakes of health workers when dressing and removing the $\mathrm{PPE}^{(36)}$.
This situation is aggravated if we consider that screening of health workers based only on signs and symptoms of COVID-19 may fail in determining the actual number of individuals infected by SARS-CoV-2 in this population. According to a study, approximately half of the health workers diagnosed with laboratory tests were asymptomatic or pre-symptomatic at the time they took the tests. Note that even individuals not presenting the clinical conditions characteristic of COVID-19 have the potential to propagate the virus ${ }^{(37)}$.

In this sense, as reported by the study using polycotton fabric (composed of polyester and cotton) impregnated with silver nanoparticles, positive results were obtained in only two minutes $99 \%$ of the times when SARS-CoV-2 was reapplied to the textile surface ${ }^{(38)}$. Thus, the use of fabrics impregnated with antimicrobial substances may be an alternative to prevent infection by this virus when present on textile surfaces used by health workers and patients to minimize infection, contamination, and finally control its outbreak.

Furthermore, given the current COVID-19 pandemic, health workers need to wear PPEs for prolonged periods when providing care, especially among patients infected by SARS-CoV-2. PPEs can lead to adverse skin reactions due to increased heat and sweat. One of the studies reported dry skin, itching, rash, and hives ${ }^{(39)}$. Therefore, in addition to inhibiting the propagation of the SARSCoV-2, textiles impregnated with silver nanoparticles are promising as they do not favor the occurrence of adverse reactions, photosensitization, or photo-irritation on the skin(38).

We acknowledge that certain substances with antimicrobial properties, which are used to impregnate textiles, may cause side effects in the short or long term, due to direct contact with skin, for instance: allergies, changes in the microbiota, and toxicity(40-41). Thus, this study's findings include the implications of using potentially toxic substances to impregnate textiles, as there is a possibility that these be harmful to health when in contact with the skin. This analysis is necessary to determine risk-benefits, especially in the long term, considering the implementation of these textiles in health services.

Another aspect that should be taken into account is that technological resources intended to prevent microbial and SARS-CoV-2 contamination depend on health workers being aware of and implementing undoubtedly effective strategies that promote biosafety in health care settings. These include hand hygiene ${ }^{(5-6)}$, surface disinfection, proper handling of materials and equipment used in health care delivery, and PPEs, among other asepsis and antisepsis measures ${ }^{(29-30)}$.

As for the applicability of textiles impregnated with antimicrobial agents, there is great versatility, considering 
that these fabrics can be used in clothing/uniforms, bed and bath linens, and even in the packaging of surgical materials.

Nonetheless, there is still a need to consider that there are no studies addressing fabrics impregnated with antimicrobial agents designated to manufacture coats. One of the in vitro studies confirms the need for further studies addressing this topic, in which the authors report that coats manufactured with polyester do not present a physical barrier against fluids and bacteria(42). These results are of concern, considering that this piece of PPE is widely used at all levels of health care delivery, although it does not seem to provide proper protection to workers.

This study presents important methodological limitations because, despite the large number of studies addressing the impregnation of textiles with antimicrobial agents, few were intervention studies, that is, studies that permit verifying efficacy in real contexts of health care delivery. Additionally, the results portray scientific evidence that concerns the time and space addressed here. The inclusion of only five databases may not have been sufficient to exhaust the scientific literature addressing the topic, which may have led to the noninclusion of eligible studies in this review.

This integrative review contributes to biosafety promotion. It opens up the possibility of implementing fabrics impregnated with antimicrobial agents in health services, especially in patients' clothing, towels, and bedding, due to the results concerning decreased microbial load and HAIs. Moreover, if this intervention is supported by public health policies and implemented in clinical practice, it may become an important tool to mitigate the course of the COVID-19 pandemic.

\section{Conclusion}

The use of fabrics impregnated with antimicrobial substances, especially by patients, is a viable alternative to prevent and control microbial transmission in health services. The use of these fabrics in the manufacturing of health workers' uniforms, however, requires further investigation to verify their effectiveness in decreasing the microbial load in clinical practice.

\section{References}

1. Ministério da Saúde (BR). Agência Nacional de Vigilância Sanitária. Medidas de Prevenção de Infecção Relacionada à Assistência à Saúde. [Internet]. $2^{\circ}$ ed. Brasília: ANVISA; 2017 [Acesso 13 abr 2020]. Disponível em: http://portal. anvisa.gov.br/documents/33852/3507912/Caderno+4++Medidas+de+Preven $\% \mathrm{C} 3 \% \mathrm{~A} 7 \% \mathrm{C} 3 \% \mathrm{~A} 30+$ de+Infec\%C $3 \% \mathrm{~A} 7 \% \mathrm{C} 3 \% \mathrm{~A} 30+$ Relacionada+\%C3\%A0+Assist $\% \mathrm{C} 3 \% \mathrm{~A}$
Ancia+\%C3\%A0+Sa\%C3\%BAde/a3f23dfb-2c54-4e64881 c-fccf9220c373

2. Bockmühl DP, Schages J, Rehberg L. Laundry and textile hygiene in healthcare and beyond. Microb Cell. 2019;6(7):299-306. doi: https://doi.org/10.15698/ mic2019.07.682

3. Chiereghin A, Felici S, Gibertoni D, Foschi C, Turello G, Piccirilli G, et al. Microbial Contamination of Medical Staff Clothing During Patient Care Activities: Performance of Decontamination of Domestic Versus Industrial Laundering Procedures. Curr Microbiol. 2020;77(7):1159-66. doi: https://doi.org/10.1007/s00284-020-01919-2

4. Riley K, Williams J, Owen L, Shen J, Davies A, Laird K. The Effect of Low-Temperature Laundering and Detergents on the Survival of Escherichia coli and Staphylococcus aureus on Textiles Used in Healthcare Uniforms. J Appl Microbiol. 2017;123(1):280-6. doi: https://doi. org/10.1111/jam.13485

5. Knepper BC, Miller AM, Young HL. Impact of an Automated Hand Hygiene Monitoring System Combined With a Performance Improvement Intervention on Hospital-Acquired Infections. Infect Control Hosp Epidemiol. 2020;41(8):931-7. doi: https://doi. org/10.1017/ice.2020.182

6. Durant DJ, Willis L, Duvall S. Adoption of Electronic Hand Hygiene Monitoring Systems in New York State Hospitals and the Associated Impact on Hospital-Acquired C. difficile Infection Rates. Am J Infect Control. 2020;48(7):733-9. doi: https://doi.org/10.1016/j.ajic.2020.04.005

7. Goyal S, Khot SC, Ramachandran V, Shah KP, Musher DM. Bacterial contamination of medical providers' white coats and surgical scrubs: a systematic review. Am J Infect Control. 2019;47(8):994-1001. doi: https://doi. org/10.1016/j.ajic.2019.01.012

8. Deshmukh SP, Patil SM, Mullani SB, Delekar SD. Silver nanoparticles as an effective disinfectant: a review. Mater Sci Eng C Mater Biol Appl. 2019;97:954-65. doi: https:// doi.org/10.1016/j.msec.2018.12.102

9. Rodrigues AG, Gonçalves PJRO, Ottoni CA, Ruiz RC, Morgano MA, Araújo WL, et al. Functional textiles impregnated with biogenic silver nanoparticles from Bionectria ochroleuca and its antimicrobial activity. Biomed Microdevices. 2019;21(3):56. doi: https://doi. org/10.1007/s10544-019-0410-0

10. Hu R, Zhao Z, Zhou J, Fan T, Liu Y, Zhao T, et al. Ultrasound Assisted Surface Micro-Dissolution to Embed Nano $\mathrm{TiO}_{2}$ on Cotton Fabrics in $\mathrm{ZnCl}_{2}$ Aqueous Solution. Ultrason Sonochem. 2019;56:160-6. doi: https://doi. org/10.1016/j.ultsonch.2019.04.006

11. Staneva D, Vasileva-Tonkova E, Grabchev I. A New Bioactive Complex Between Zn(II) and a Fluorescent Symmetrical Benzanthrone Tripod for an Antibacterial 
Textile. Materials (Basel). 2019;12(21):3473. doi: https:// doi.org/10.3390/ma12213473

12. World Health Organization. Coronavirus disease 2019 (COVID-19): Situation Report - 195. [Internet]. Geneva: WHO; 2020 [cited Aug 3, 2020]. Available from: https://www.who.int/docs/default-source/coronaviruse/ situation-reports/20200802-covid-19-sitrep-195. pdf?sfvrsn=5e5da0c5_2

13. Rothan HA, Byrareddy SN. The epidemiology and pathogenesis of coronavirus disease (COVID-19) outbreak. J Autoimmun. 2020;109:102433. doi: https://doi. org/10.1016/j.jaut.2020.102433

14. Chin AWH, Chu JTS, Perera MRA, Hui KPY, Yen HL, Chan MCW, et al. Stability of SARS-CoV-2 in different environmental conditions. Lancet Microbe. 2020;1(1):e10. doi: https://doi.org/10.1016/S2666-5247(20)30003-3 15. Martín-Vaquero Y, González-Sanz A, Muñoz-Martín B. Safe handling of clothing and hygiene of patients and health professionals: Scoping review. Enferm Clin. 2020. doi: https://doi.org/10.1016/j.enfcli.2020.05.014

16. Centers for Disease Control and Prevention. Coronavirus Disease 2019 (COVID-19): Cases \& Deaths among Healthcare Personnel. [Internet]. USA: CDC; 2020 [cited Aug 20, 2020]. Available from: https://www.cdc.gov/ coronavirus/2019-ncov/cases-updates/cases-in-us.html

17. Adalja AA, Toner E, Inglesby TV. Priorities for the US Health Community Responding to COVID-19. JAMA. 2020;323(14):1343-4. doi: https://doi.org/10.1001/ jama.2020.3413

18. Whittemore $\mathrm{R}, \mathrm{Knafl} \mathrm{K}$. The integrative review: updated methodology. J Adv Nurs. 2005;52(5):546-53. doi: https://doi.org/10.1111/j.1365-2648.2005.03621.x 19. Pearson A, White H, Bath-Hextall F, Apostolo J, Salmond S, Kirkpatrick P. Methodology for JBI Mixed Methods Systematic Reviews. In: The Joanna Briggs Institute, ed. The Joanna Briggs Institute Reviewers' Manual 2014. [Internet]. Adelaide: The University of Adelaide; 2014 [cited Aug 5, 2020]. Available from: https://nursing.Isuhsc.edu/JBI/docs/ReviewersManuals/ Mixed-Methods.pdf

20. Schünemann H, Brożek J, Guyatt G, Oxman A. GRADE Handbook. Handbook for grading the quality of evidence and the strength of recommendations using the GRADE approach. [Internet]. The GRADE Working Group; 2013 [cited Aug 26, 2020]. Available from: https://gdt. gradepro.org/app/handbook/handbook.html

21. Marcus EL, Yosef $H$, Borkow G, Caine $Y$, Sasson A, Moses AE. Reduction of health care-associated infection indicators by copper oxide-impregnated textiles: Crossover, double-blind controlled study in chronic ventilator-dependent patients. Am J Infect Control. 2017;45(4):401-3. doi: https://doi.org/10.1016/j. ajic.2016.11.022
22. Irfan $M$, Perero $S$, Miola $M$, Maina G, Ferri A, Ferraris $M$, et al. Antimicrobial functionalization of cotton fabric with silver nanoclusters/silica composite coating via RF co-sputtering technique. Cellulose. 2017;24(5):2331-45. doi: https://doi.org/10.1007/s10570-017-1232-y

23. Anderson DJ, Addison R, Lokhnygina $Y$, Warren $B$, Sharma-Kuinkel B, Rojas LJ, et al. The Antimicrobial Scrub Contamination and Transmission (ASCOT) Trial: A Three-Arm, Blinded, Randomized Controlled Trial With Crossover Design to Determine the Efficacy of Antimicrobial Impregnated Scrubs in Preventing Healthcare Provider Contamination. Infect Control Hosp Epidemiol. 2017;38(10):1147-54. doi: https://doi.org/10.1017/ ice. 2017.181

24. Gerba CP, Sifuentes LY, Lopez GU, Abd-Elmaksoud S, Calabrese J, Tanner B. Wide-spectrum activity of a silverimpregnated fabric. Am J Infect Control. 2016;44(6):68990. doi: https://doi.org/10.1016/j.ajic.2015.11.033

25. Sifri CD, Burke GH, Enfield KB. Reduced health care-associated infections in an acute care community hospital using a combination of self-disinfecting copperimpregnated composite hard surfaces and linens. Am J Infect Control. 2016;44(12):1565-71. doi: https://doi. org/10.1016/j.ajic.2016.07.007

26. Lazary A, Weinberg I, Vatine JJ, Jefidoff A, Bardenstein R, Borkow G, et al. Reduction of healthcareassociated infections in a long-term care brain injury ward by replacing regular linens with biocidal copper oxide impregnated linens. Int J Infect Dis. 2014;24:23-9. doi: https://doi.org/10.1016/j.ijid.2014.01.022

27. Groß R, Hubner N, Assadian O, Jibson B, Kramer A, Working Section for Clinical Antiseptic of the German Society for Hospital Hygiene. Pilot study on the microbial contamination of conventional vs. silver-impregnated uniforms worn by ambulance personnel during one week of emergency medical service. GMS Krankenhhyg Interdiszip. 2010;5(2):Doc09. doi: https://doi.org/10.3205/ dgkh000152

28. Javadhesari SM, Alipour S, Mohammadnejad S, Akbarpour MR. Antibacterial activity of ultra-small copper oxide (II) nanoparticles synthesized by mechanochemical processing against S. aureus and E. coli. Mater Sci Eng C Mater Biol Appl. 2019;105:110011. doi: https://doi. org/10.1016/j.msec.2019.110011

29. Lee JJ, Hwang SJ, Huang JF. Review of the Present Features and the Infection Control Challenges of COVID-19 Pandemic in Dialysis Facilities. Kaohsiung J Med Sci. 2020 Jun;36(6):393-8. doi: https://doi.org/10.1002/ kjm2.12239

30. Li Y, Li J, Hu T, Hu J, Song N, Zhang Y, et al. Five-year Change of Prevalence and Risk Factors for Infection and Mortality of Carbapenem-Resistant Klebsiella pneumoniae Bloodstream Infection in a Tertiary Hospital in North 
China. Antimicrob Resist Infect Control. 2020;9(1):79. doi: https://doi.org/10.1186/s13756-020-00728-3

31. Adeyemi OS, Shittu EO, Akpor OB, Rotimi D, Batilha GE. Silver nanoparticles restrict microbial growth by promoting oxidative stress and DNA damage. EXCLI J. 2020;19:492-500. doi: https://doi.org/10.17179/ excli2020-1244

32. Liu Y, Ning Z, Chen Y, Guo M, Liu Y, Gali NK, et al. Aerodynamic Analysis of SARS-CoV-2 in Two Wuhan Hospitals. Nature. 2020 Jun;582(7813):557-60. doi: https://doi.org/10.1101/2020.03.08.982637

33. World Health Organization. Report of the WHO-China Joint Mission on Coronavirus Disease 2019 (COVID-19). [Internet]. Geneva: WHO; 2020 [cited Apr 21, 2020]. Available from: https://www.who.int/docs/default-source/ coronaviruse/who-china-joint-mission-on-covid-19-finalreport.pdf

34. Albuquerque LP, Silva RB, Araújo RMS. COVID-19: origin, pathogenesis, transmission, clinical aspects and current therapeutic strategies. Rev Pre Infec e Saúde [Internet]. 2020[cited Aug 5, 2020];6:10432. Available from: https://revistas.ufpi.br/index.php/nupcis/article/ view/10432/0

35. Rodrigues JAP, Stelmatchuk AM, Lacerda MR, Galvão CM. Covid-19 containment measures adopted in bone marrow transplantation service. Rev Bras Enferm. 2020;73(Suppl 2):e20200476. doi: https://doi. org/10.1590/0034-7167-2020-0476

36. Díaz-Guio DA, Ricardo-Zapata A, Ospina-Velez J, Gómez-Candamil G, Mora-Martinez S, RodriguezMorales AJ. Cognitive load and performance of health care professionals in donning and doffing PPE before and after a simulation-based educational intervention and its implications during the COVID-19 pandemic for biosafety. Infez Med. [Internet]. 2020 [cited Aug 5, 2020];28(Suppl 1):111-7. Available from: https://www.infezmed.it/media/ journal/Vol_28_suppl1_2020_17.pdf

37. Kimball A, Hatfield KM, Arons M, James A, Taylor J, Spicer $\mathrm{K}$, et al. Asymptomatic and Presymptomatic SARSCoV-2 Infections in Residents of a Long-Term Care Skilled Nursing Facility - King County, Washington, March 2020. MMWR Morb Mortal Wkly Rep. 2020;69(13):377-81. doi: http://dx.doi.org/10.15585/mmwr.mm6913e1

38. Tremiliosi GC, Simoes LGP, Minozzi DT, Santos RI, Vilela DCB, Durigon EL, et al. Ag nanoparticlesbased antimicrobial polycotton fabrics to prevent the transmission and spread of SARS-CoV-2. BioRxiv. 2020. doi: https://doi.org/10.1101/2020.06.26.152520

39. Hu K, Fan J, Li X, Gou X, Li X, Zhou X. The adverse skin reactions of health care workers using personal protective equipment for COVID-19. Medicine. 2020;99(24):e20603. doi: http://dx.doi.org/10.1097/MD.0000000000020603 40. Prasath S, Palaniappan K. Is using nanosilver mattresses/pillows safe? A review of potential health implications of silver nanoparticles on human health. Environ Geochem Health. 2019;41(5):2295-313. doi: https://doi.org/10.1007/s10653-019-00240-7

41. Liao C, Li Y, Tjong SC. Bactericidal and Cytotoxic Properties of Silver Nanoparticles. Int J Mol Sci. 2019;20(2):449. doi: https://doi.org/10.3390/ ijms20020449

42. Bim FL, Bim LL, Monteiro RM, Machado MB, Santos $A P$, Andrade $D$, et al. Do white coats on polyester fabrics act as a barrier against fluids and bacteria? Acta Paul Enferm. 2020; 33:eAPE20190242. doi: http://dx.doi. org/10.37689/acta-ape/2020A00242

\section{Authors' Contribution:}

Study concept and design: Guilherme Schneider, Felipe Lazarini Bim, Denise de Andrade. Obtaining data: Guilherme Schneider, Felipe Lazarini Bim. Data analysis and interpretation: Guilherme Schneider, Felipe Lazarini Bim, Álvaro Francisco Lopes de Sousa, Evandro Watanabe, Denise de Andrade, Inês Fronteira. Obtaining financing: Guilherme Schneider. Drafting the manuscript: Guilherme Schneider, Felipe Lazarini Bim, Álvaro Francisco Lopes de Sousa, Evandro Watanabe, Denise de Andrade, Inês Fronteira. Critical review of the manuscript as to its relevant intellectual content: Guilherme Schneider, Felipe Lazarini Bim, Álvaro Francisco Lopes de Sousa, Evandro Watanabe, Denise de Andrade, Inês Fronteira.

All authors approved the final version of the text.

Conflict of interest: the authors have declared that there is no conflict of interest. Creative Commons (CC BY).

This license lets others distribute, remix, tweak, and build upon your work, even commercially, as long as they credit you for the original creation. This is the most accommodating of licenses offered. Recommended for maximum dissemination and use of licensed materials. 